obtained with good definition over nearly the whole of the area. The working distance may be varied from $6 \mathrm{ft}$. to $24 \mathrm{ft}$., giving pictures from $2 \mathrm{ft}$. to $9 \mathrm{ft}$. square, with of course a diminution in intensity at the greater distances. The episcope, which costs $\$ 12$ 12s., complete with lamps, should provo particularly useful for illustrating lessons in classrooms or for demonstrations in small lecture theatres, where a very large picture is not required.

\section{Cultivation of Living Tissue Cells}

At the Friday evening discourse at the Royal Institution on November 18, Dr. R. C. Canti exhibited films demonstrating the cultivation of living tissue cells. The films consist of moving photomicrographs of the living cells of animal tissues taken whilst they are growing outside the body. The individual pictures are taken at relatively long intervals but are projected on the screen at the usual speed of 16 pictures per second. This gives the effect of speeding up and approximately three weoks continuous photography is shortened into half an hour. The first film opened with the demonstration of a 'tissue culture'. This was followed by a picture of a fragment of periosteum of the chick embryo under low magnification which shows the outwandering of the cells from the central mass or explant. Higher magnification is then employed to demonstrate the structure of vegetative cells and the classical stages of cell division. The picture then changed from healthy to malignant tissue and showed the characteristic cells of a cancerous tumour of the rat known as Jensen's rat sarcoma. Dr. Canti's second reel was devoted to a demonstration of the contents of the cell by the method of dark-ground illumination, which reveals certain structures, for example, granules and mitochondria, invisible by the ordinary methods of trans-illumination. The third reel contained subjects of embryological interest, namely, the development of the rabbit ovum from the single cell up to the morula stage, the development of the young chick embryo from the primitive stroak and the development of the bony fernur from the cartilagenous rudiment in the six-duy chick embryo. The apparatus for taking the photographs is a combination of the cinema camera, microscope and biological incubator, with a specially constructed automatic mechanism for making the exposures at the desired intervals.

\section{Colour Films}

THE paper read before the Royal Society of Arts on November 9 by Mr. 'T. Thorne Baker gave a useful account of new developments in colour cinematography. Compared with other inventions like radio-telephony, the aeroplane and sound films, the coming of photography in natural colours seems very slow. The coloured films which have been shown at many picture theatres during the last two or three years are nearly all two-colour pictures. The main drawback is that the colours obtained in these pictures are not absolutely natural. But now methods havo been devised for obtaining three- colour pictures. These require for the development of a satisfactory studio technique an immense amount of further research. In the early days of the sound film, many thought that it would have a short lifo becuuse the reproduction of both speech and music was so bad. Yet improvements have proceeded so rapidly that it is now so good that the demand for silent films has almost ceased. A similar series of events will probably take place in connexion with colour films. Most of the various attempts made to please the eye by two-colour processes have failed. It has taken years to put three-colour processes into practical form. But once the natural colour film has been seen by the public it seems that they will soon cease to think that it is a 'colour' picture and merely derive increased enjoyment from its naturalness. Similarly, the expert who is familiar with tho latest developments of colour films feels when he looks at tho ordinary film, notwithstanding the exquisite photography and the magnificent art which characterise modern productions, that a serious omission has been made.

\section{The Past and the Future in Psychical Research}

Srr Oliver Lodge, in his presidential address to the Society for Psychical Research on the occasion of its jubilee in June, discussed the past and the future with special reference to the history of the Society. He recalled the events of the last fifty years and notod how the disapproval and hostility which was encountered in the early years of the Society's existence are gradually diminishing. The hostility, he maintained, was directed mainly by spiritualists, who disapproved of the cautious procedure of the Society's officers and of the criticism to which narratives were subjected before publication. Although this can scarcely be maintained at the present day, it is true that the founders of the Society, with the establishment of thought transference as their primary aim, were, in fact, endeavouring to apply the scientific method to their inquiries. In his insistence on this Sir Oliver is justified, in spite of such famous cases as that of Sir E. Hornby in 1884, where some attention to essential details would have absolved Mr. Frederic Myers and Mr. Edmund Gurney from charges of carelessness in the proparation of their data.

IN his further discussion of the past, Sir Oliver asked his audience to remember the pioneer work of Myers, who, although of literary and even perhaps mystical tendencies, nevertheless realised the import. ance of the scientific treatment of those problems which were his greatest interest. To convince the world of telepathy was the dominant note of the early years : to-day, Sir Oliver thinks, may be the time for the Society in its corporate capacity to declare its belief in the reality of the spiritual world and in its interaction with the physical one. It is on this note that the address ends, and it finally concludes by Sir Oliver again asserting his personal belief in the "cosmic and permanent" existence of the human spirit apart from the discarded material organism, with its memory, character and affections intact.

$$
\text { No. 3291, Vol. 130] }
$$

